Article

\title{
Optimization and Application of a GC-MS Method for the Determination of Endocrine Disruptor Compounds in Natural Water
}

\author{
José Gustavo Ronderos-Lara ${ }^{1}$, Hugo Saldarriaga-Noreña ${ }^{1, *(D)}$, Mario Alfonso Murillo-Tovar 2 (ID) \\ and Josefina Vergara-Sánchez ${ }^{3}$ (D) \\ 1 Centro de Investigaciones Químicas, Instituto de Investigación en Ciencias Básicas y Aplicadas, Universidad \\ Autónoma del Estado de Morelos, Av. Universidad 1001, 62209 Cuernavaca, Mexico; ronderos92@gmail.com \\ 2 Cátedras, Consejo Nacional de Ciencia y Tecnología, Av. Insurgentes Sur 1582, Colonia Crédito Constructor, \\ Del. Benito Juárez, 03940 Ciudad de México, Mexico; mario.murillo@uaem.mx \\ 3 Laboratorio de Análisis y Sustentabilidad Ambiental, Escuela de Estudios Superiores de Xalostoc, \\ Universidad Autónoma del Estado de Morelos, 62715 Ayala, Morelos, Mexico; vergara@uaem.mx \\ * Correspondence: hsaldarriaga@uaem.mx; Tel.: +52-777-329-7997
}

Received: 25 April 2018; Accepted: 31 May 2018; Published: 19 June 2018

check for updates

\begin{abstract}
Bisphenol A (BPA), 4-nonylphenol (4NP), estradiol ( $\left.\mathrm{E}_{2}\right)$, and ethinylestradiol ( $\left.\mathrm{EE}_{2}\right)$ are considered as endocrine disruptors or mutagens. These compounds are commonly called endocrine disrupter chemicals (EDCs). BPA and 4NP are widely used as plastic additives, lacquers, resins, or surfactants, while $E_{2}$ is one of the predominant female sex hormones during the reproductive years, and $\mathrm{EE}_{2}$ is an estrogen derived from estradiol, used in the production of contraceptive pills. All of these can be usually found in wastewater. In Mexico, it is common for water from rivers, lakes, and canyons to be reused for different purposes. Unfortunately, there is little information on the concentration of many of the pollutants present in such bodies of water. To determine the presence of these compounds in samples of wastewater in the Apatlaco River, an accurate and reproducible method was developed by coupling gas chromatography to mass spectrometry (GC-MS). A solid-phase extraction with Chromabond RP-18 cartridges was carried out, and the elution was performed with an acetone/methanol mixture. After isolation, the solvent was removed and a silylation step was carried out using N,O-bis(trimethylsilyl)trifluoroacetamide (BSTFA). Recoveries for spiked samples were between $71.8 \%$ and $111.0 \%$. The instrumental limits of detection (IDL) ranged between 24.7 and $37.0 \mathrm{ng} \mathrm{mL}^{-1}$. In total, 16 samples were taken in 2015 at the microbasin of the Apatlaco River, located in the state of Morelos. The maximum concentrations found were $4 \mathrm{NP}$ (85.5 $\left.\mathrm{ng} \mathrm{mL}^{-1}\right)$, BPA (174.6 $\left.\mathrm{ng} \mathrm{mL}^{-1}\right), \mathrm{E}_{2} 103.6\left(\mathrm{ng} \mathrm{mL}^{-1}\right)$, and $\mathrm{EE}_{2}\left(624.3 \mathrm{ng} \mathrm{mL}^{-1}\right)$.
\end{abstract}

Keywords: endocrine disruptors; surface water; environmental risk; GC-MS

\section{Introduction}

The presence of endocrine disrupter chemicals (EDCs) in water is harmful to the development of biota and to human health. Once in the environment, these compounds can be transported by the aquatic current, deposited on the bottom of bodies of surface water, stored in sediments, and/or bioaccumulate [1]. In Mexico, this situation constitutes a high risk, since rivers and lakes are frequently used in the irrigation of crops, fish farming, and recreational activities. Also, there is a lack of information on the content of EDCs in surface water, in part because most of the studies have focused mainly on the determination of heavy metals [2-5].

In the state of Morelos, there are several bodies of surface water which have suffered significant deterioration because some of them are the destination of wastewater discharges generated from daily 
activities. The sector of agriculture in Morelos uses approximately 800 thousand $\mathrm{m}^{3} /$ year of surface water, while altogether, domestic, urban, industrial, and recreational activities use approximately 60 thousand $\mathrm{m}^{3}$ /year of surface water [6]. A specific case is the microbasin of the Apatlaco River, which emerges as a channel in the Chapultepec spring in Cuernavaca, Morelos, Mexico. It flows into the Yautepec River, which in turn, flows into the Amacuzac River, and discharges its waters into the Balsas River, to end its path in the Pacific Ocean. This body of water is important for the development of daily life in some places in the state of Morelos, and its waters are used mainly to feed agricultural irrigation systems, contributing approximately 186 thousand $\mathrm{m}^{3}$ /year [5], in addition to having a great diversity of aquatic species.

The basin is located northwest of the state of Morelos and covers approximately $746 \mathrm{~km}^{2}$ of the total surface of state of Morelos [7]. The formation of the Apatlaco River is mainly due to the runoff of water that flows through the soil. This river presents a decline that goes from 3690 to $880 \mathrm{~m}$ above sea level [6]. During this path, it receives the direct discharge of residual waters that come from diverse activities, residential, agricultural, industrial, and hospital zones.

For this reason, this study aims to establish environmental levels of four endocrine disrupting compounds (17 $\alpha$-ethinylestradiol, $17 \beta$-estradiol, 4-nonylphenol, and bisphenol-A), all them considered markers of anthropic activities, using gas chromatography and mass spectrometry (GC-MS). Also, the health risk derived from the presence of these substances in the surface water that flows through the microbasin of the Apatlaco River will be evaluated.

\section{Material and Methods}

\subsection{Reagents and Materials}

All used reagents were analytical grade. 4-Nonylphenol ( $\geq 99.8 \%), 17 \alpha$-ethynilestradiol $(\geq 98.0 \%)$, and $17 \beta$-estradiol ( $\geq 98.0 \%$ ) were obtained from Sigma-Aldrich (St. Louis, MO, USA) and Bisphenol A (99.0\%) from Supelco (St. Louis, MO, USA). Meanwhile N,O-bis(trimethylsilyl)-trifluoroacetamide + trimethyl-chlorosilane, HPLC water, and pyridine ( $\geq 99 \%)$ were obtained from Sigma Aldrich. Acetone (99.9\%) was purchased from Meyer (México City, México) and methanol (99.7\%) from Fermont (Monterrey, N.L., México). The Millipore nylon filters from Pall Corporation (Ann Arbor, MI, USA) and solid phase extraction cartridges $C_{18}(500 \mathrm{mg} / 6 \mathrm{~mL})$ were bought from Chromabond (Düren, Germany).

\subsection{Standard Preparation}

Individually, approximately $1 \mathrm{mg}$ of standard was dissolved in acetone. Then, a series of dilutions was made to obtain a calibration curve with five different concentration levels $(5,25,125,250$, and $500 \mathrm{ng} \mathrm{mL}^{-1}$ ). To evaluate extraction efficiency, repeatability, and reproducibility, a synthetic sample was prepared $\left(80 \mathrm{ng} \mathrm{mL}^{-1}\right)$.

\subsection{Extraction and Elution}

A synthetic sample of $500 \mathrm{~mL}$ was extracted in $\mathrm{C}_{18}$ cartridges previously conditioned using 6 $\mathrm{mL}$ of methanol/acetone (3:2), followed by $6 \mathrm{~mL}$ of methanol, and finally, $6 \mathrm{~mL}$ of reagent water. Spiked samples were passed through the cartridge applying vacuum at a flow rate of $6.0 \mathrm{~mL} \mathrm{~min}-1$. The elution of retained compounds was performed using $10 \mathrm{~mL}$ of methanol/acetone (3:2). Eluates were reduced in a rotary evaporator until the volume was approximately $1 \mathrm{~mL}$, and the remaining solvent was completely eliminated by applying a soft stream of nitrogen (99.99\%).

\subsection{Derivatization}

The dry extract was resuspended in $50 \mu \mathrm{L}$ of pyridine and $50 \mu \mathrm{L}$ of derivatizing agent BSTFA + TMCS (99:1). Then, to complete the reaction of derivatization, vials were submerged in a water bath $\left(60{ }^{\circ} \mathrm{C}\right)$ for $60 \mathrm{~min}$. 


\subsection{Gas Chromatography in Tandem with Mass Spectrometry}

The derivatized samples were analyzed in Agilent Technologies gas chromatograph (GC), model 6890 coupled to a mass spectrometer (MS) 5973. The separation of compounds was performed in an HP-5MS $30 \mathrm{~m} \times 0.25 \mathrm{~mm}$ capillary column, and $0.25 \mu \mathrm{m}$ film thickness (Agilent, Santa Clara, CA, USA). Carrier gas was helium (99.998\%) at a flow rate of $1 \mathrm{~mL} \mathrm{~min}^{-1}$. The injector temperature was $300{ }^{\circ} \mathrm{C}$ in splitless mode using an injection volume of $1.0 \mu \mathrm{L}$. The oven program started at $150{ }^{\circ} \mathrm{C}$ and was maintained for $2 \mathrm{~min}$, then the temperature was incremented at $15^{\circ} \mathrm{C}$ per minute to reach $250{ }^{\circ} \mathrm{C}$, then immediately incremented at $5^{\circ} \mathrm{C}$ per minute until it reached $280^{\circ} \mathrm{C}$, where it was held for $15 \mathrm{~min}$. The MS was operated in electron impact mode $(70 \mathrm{eV})$, holding the temperatures of the ion source and quadrupole filter at $230^{\circ} \mathrm{C}$ and $150{ }^{\circ} \mathrm{C}$, respectively (Table 1 ).

Table 1. Monitored ions $(\mathrm{m} / \mathrm{z})$ in mass spectrometry for each of the trimethylsilyl derivated (TMS) compounds of interest.

\begin{tabular}{cccccc}
\hline Compound & $\begin{array}{c}\text { Molecular } \\
\text { Weight (g/mol) }\end{array}$ & $\begin{array}{c}\text { Trimethylsilyl } \\
\text { Derivated Compound }\end{array}$ & $\begin{array}{c}\text { Molecular } \\
\text { Weight (g/mol) }\end{array}$ & $\begin{array}{c}\text { Ion } \\
\text { Quantitation }\end{array}$ & $\begin{array}{c}\text { Ion } \\
\text { Confirmation }\end{array}$ \\
\hline $4 \mathrm{NP}$ & 220.35 & TMS-4NP & 292.54 & 292 & 207,277 \\
$\mathrm{BPA}$ & 228.29 & TMS-BPA & 372.65 & 357 & $372,207,73$ \\
$\mathrm{E}_{2}$ & 272.38 & TMS-E & 416.75 & 416 & $285,232,129$ \\
$\mathrm{EE}_{2}$ & 296.40 & ${\mathrm{TMS}-E_{2}}$ & 440.77 & 425 & $440,300,285$ \\
\hline
\end{tabular}

\subsection{Application on Natural Water Samples}

The samples were collected according the to the United States Environment Protection Agency method 1698 [8], briefly, the samples were collected in amber glass bottles, previously conditioned and maintained at $4{ }^{\circ} \mathrm{C}$ while transporting to a laboratory. Before extraction, samples were filtered through a nylon filter $(0.45 \mu \mathrm{m})$. In total, 16 samples were collected during November and December 2015 (after the rainy season) in the basin of Apatlaco in three different municipalities: Cuernavaca, Temixco, and Jiutepec (Figure 1).

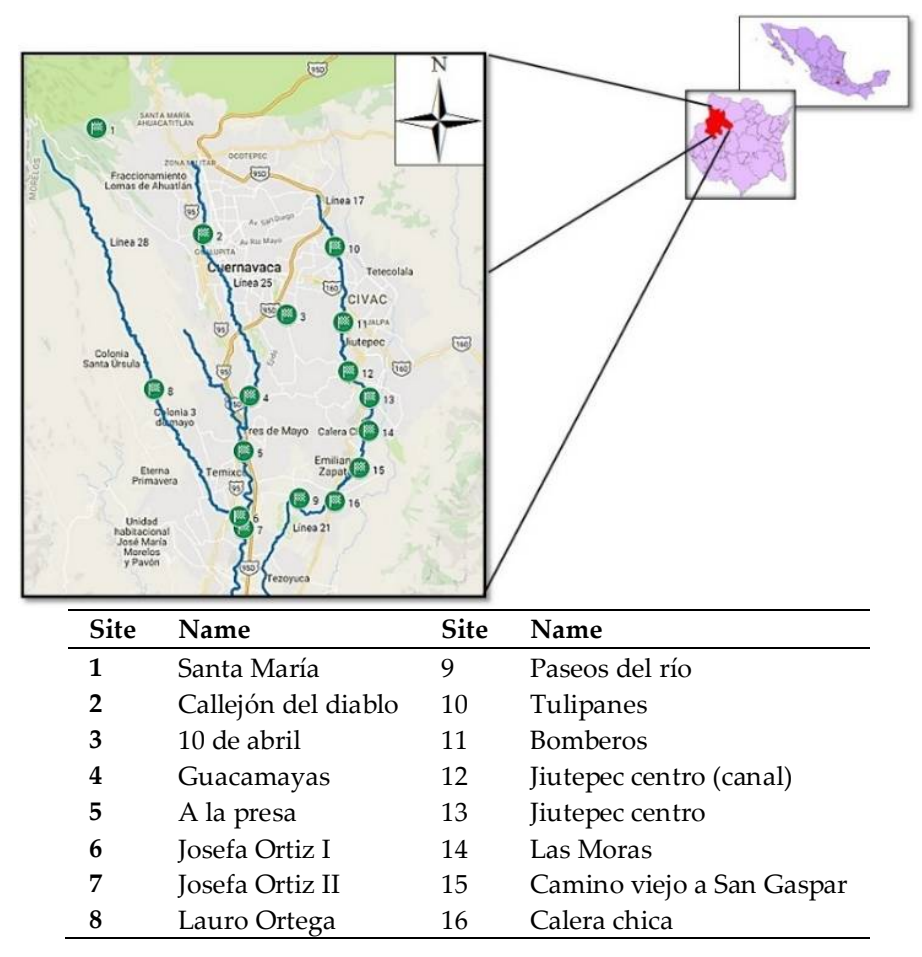

Figure 1. Location of the sampling sites. 


\section{Results and Discussion}

\subsection{Optimization of the Analytical Conditions}

Selectivity was determined by the complete separation of the four compounds by gas chromatography, and the complete absence of interference signals. Linearity was calculated by means of the correlation coefficient $(r)$ obtained from the calibration curve. Extraction efficiency was evaluated by passing $500 \mathrm{~mL}$ of synthetic samples $(80 \mathrm{ng} / \mathrm{mL})$ through a $\mathrm{C}_{18}$ cartridge. Repeatability was evaluated analyzing synthetic samples in duplicate, and the same day and reproducibility was evaluated analyzing synthetic samples in different days. Instrumental limits of detection (IDL) were determined according to Miller \& Miler (2010), using the concentration that provides a signal that is equal to the signal corresponding to the blank $\left(Y_{B}=S_{y / x}\right)$, plus three times the standard deviation of the blank $\left(S_{B}=a\right)[9]$.

$$
\mathrm{IDL}=Y_{B}+3^{*} S_{B}
$$

$Y_{B}=S_{y / x}:$ random error in the direction of " $y$ "

$S_{B}=a:$ intercept.

Standard sample blanks were injected to ensure absence of any impurities, which affect the selectivity. The retention times obtained were 9.7, 11.6, 15.8, and 16.9 min for $4 \mathrm{NP}, \mathrm{BPA}, \mathrm{E}_{2}$, and $\mathrm{EE}_{2}$, respectively (Figure 2). Linearity was determined using the correlation coefficient $(r)$ calculated for each calibration graph, 4NP (0.9927), BPA (0.9904), $\mathrm{E}_{2}(0.9917)$, and $\mathrm{EE}_{2}(0.9800)$.

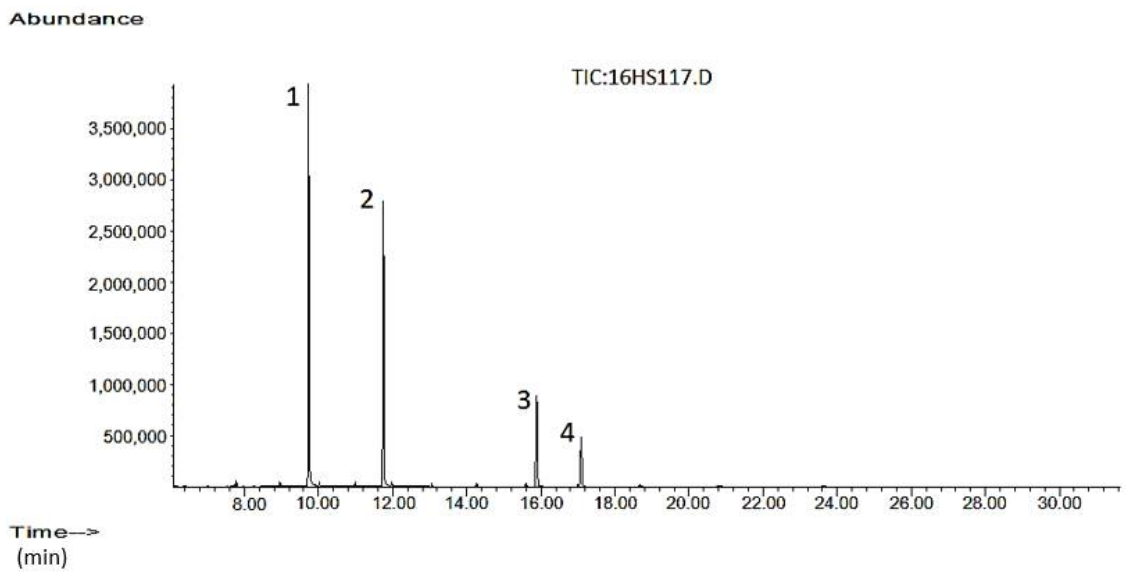

Figure 2. Retention times of endocrine disrupter chemicals (EDCs). 1: TMS-4NP, 2: TMS-BPA, 3: TMS-E 2 , 4: TMS-EE 2 .

Recovery percentages ranged between 78.3 (for $\mathrm{EE}_{2}$ ) and 111.0\% (for BPA). Precision, in terms of repeatability and reproducibility, indicated satisfactory results considering relative standard deviation, which in all cases was below $10 \%$. This agrees with terms established by United States Protection Agency (USEPA) for environment samples that consider a maximum variation of $30 \%$ as acceptable. On the other hand, IDL ranges were between 24.7 (for $\mathrm{EE}_{2}$ ) and 37.0 (for BPA) (Table 2).

Table 2. Results for evaluation of analytical method.

\begin{tabular}{ccccccc}
\hline Compound & $\boldsymbol{T}_{\boldsymbol{R}}$ & $\boldsymbol{r}$ & $\begin{array}{c}\text { Repeatability } \\
\text { (\% RSD) }\end{array}$ & $\begin{array}{c}\text { Reproducibility } \\
\text { (\%) RSD) }\end{array}$ & \% Recovery ${ }^{(\mathbf{( 2 )})}$ & IDL \\
\hline 4NP & 9.7 & 0.9927 & 8.2 & 5.2 & $107.6 \pm 22.5$ & 26.6 \\
BPA & 11.6 & 0.9904 & 0.9 & 7.2 & $111.0 \pm 6.2$ & 37.0 \\
E $_{2}$ & 15.8 & 0.9917 & 3.1 & 10.5 & $71.8 \pm 17.3$ & 29.0 \\
EE $_{2}$ & 16.9 & 0.9800 & 6.3 & 5.1 & $78.3 \pm 20.5$ & 24.7 \\
\hline
\end{tabular}

$T_{R}$ : retention time. $r$ : correlation coefficient. IDL: instrumental detection limit $(\mathrm{ng} / \mathrm{mL}) .{ }^{(2)},{ }^{(3)}$ and ${ }^{(4)}$ : number of dates for calculation. 


\subsection{Application on Natural Water Samples}

Table 3 shows the concentration found in natural water samples taken in the Apatlaco river basin, as well as comparisons with respect to concentrations reported in State of Hidalgo and Xochimilco in Mexico City. In five sites, no EDCs were detected (Santa María, Callejón del diablo, Lauro Ortega, Tulipanes, and Camino Viejo a San Gaspar). In Santa María and Lauro Ortega sites, the absence of EDCs is probably because it is an uninhabited place, meanwhile, in Callejón del Diablo, Tulipanes, and Camino Viejo a San Gaspar, probably the high volume of rainfall that occurred prior to sampling could have affected the dilution of these compounds (rainfall average $37.6 \mathrm{~mm} / \mathrm{m}^{2}$ ) [10]. Only in one site studied were EDCs detected (a la Presa), probably due to house room density near the river.

Table 3. EDC concentrations detected in surface water samples and comparisons with respect to other studies carried out in Hidalgo State, México, and México City $\left(\mathrm{ng} \mathrm{mL}^{-1}\right)$.

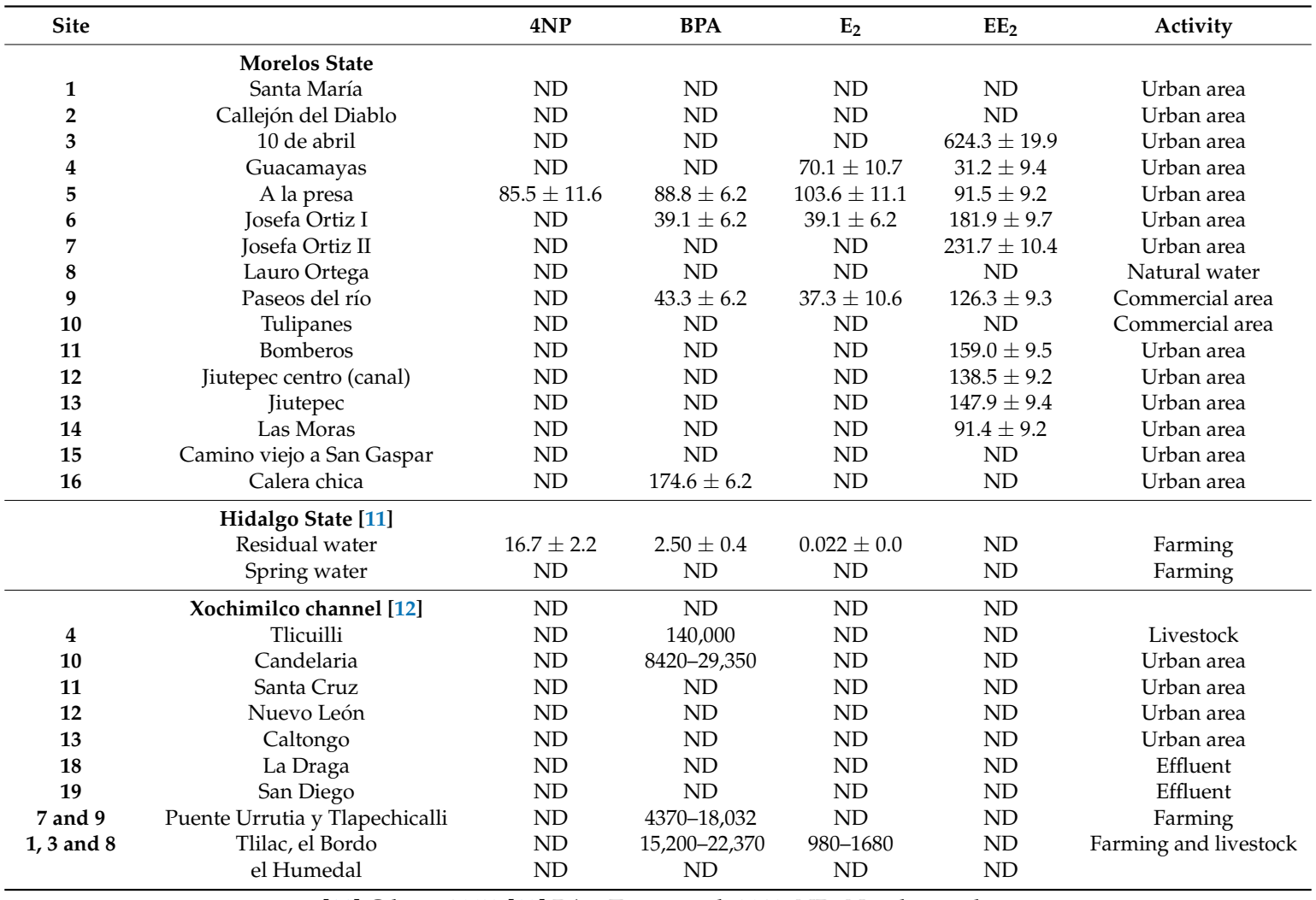

[11] Gibson 2007; [12] Díaz-Torres et al. 2013; ND: Not detected.

In Mexico, there is a little information about maximum concentrations of EDCs in natural water, and neither a norm that regulate them, and for this reason, in this study, we took into consideration, the USEPA regulation rules for $4 \mathrm{NP}$ and BPA, and the European Union regulations for $\mathrm{E}_{2}$ and $\mathrm{EE}_{2}$, with the purpose of making comparisons and to have reference concentrations.

The compound that presented the highest concentration was $\mathrm{EE}_{2}\left(624.3 \mathrm{ng} \mathrm{mL}^{-1}, 10\right.$ de abril site) followed by $\mathrm{E}_{2}$ (103.6 $\mathrm{ng} \mathrm{mL} \mathrm{mL}^{-1}$, A la Presa site). The site that presented all compounds was "A la Presa", meanwhile, BPA was detected only in six sites (10 de abril, A la Presa, Josefa Ortiz I, Josefa Ortiz II, Paseos del río and Calera chica) in a range of concentrations between 39.1 and $174.6 \mathrm{ng} \mathrm{mL}^{-1}$. With regard to this, the USEPA has suggested $1.78 \mathrm{ng} \mathrm{mL}^{-1}$ as the maximum concentration for BPA in surface water from United States of America [13]. For its part, 4NP was detected less frequently (only in one site, A la Presa site) at $85.6 \mathrm{ng} \mathrm{mL}^{-1}$, and this concentration exceeds the concentration established by USEPA in surface water $\left(6.6 \mathrm{ng} \mathrm{mL}^{-1}\right)$ [14].

$\mathrm{E}_{2}$ it was detected only in three of the 16 analyzed samples (Guacamayas, A la Presa and Paseos del río). The concentration levels were in a range from 37.3 to $103.6 \mathrm{ng} \mathrm{mL}^{-1}$. These concentrations 
were at least three magnitudes of order greater than the concentration $0.002 \mathrm{ng} \mathrm{mL}^{-1}$ suggested by EU for surface water [15].

The compound that presented the highest concentrations and frequency was $\mathrm{EE}_{2}$, which was detected in 10 of 16 analyzed samples. The interval of concentrations was between 31.2 and $624.3 \mathrm{ng} \mathrm{m}^{-1}$, and these values exceed, extremely, the concentration recommended by European Union $\left(0.0001 \mathrm{ng} \mathrm{mL}^{-1}\right)$ [16].

The obtained results reveal that levels of EDCs in the studied sites in Morelos State, México, are higher than levels of EDCs found in other places in the republic, such as Hidalgo State, México, where the presence of $4 \mathrm{NP}, \mathrm{E}_{2}$, and $\mathrm{EE}_{2}$ were reported in surface water used specifically for crop irrigation [11]. Meanwhile, the levels of BPA and $E_{2}$ reported in surface water from Xochimilco Lake in México City [12], are higher than the levels of EDCs observed in this study (Table 3).

\subsection{Evaluation of Health Risk by EDC Exposure}

To predict the healthy adverse effects of exposition to $4 \mathrm{NP}, \mathrm{BPA}, \mathrm{E}_{2}$, and $\mathrm{EE}_{2}$ present in analyzed water, it a risk evaluation was carried out in accordance with USEPA method [17]. Considering that exposure sensibility to EDC in adult and young dwellers is different, for this reason, two different scenarios were considered, one for children and the other one for adults. In both cases, the exposition frequency was 365 days. Reference body weight for adult was $70 \mathrm{~kg}$, and average EDC contact was $2 \mathrm{~L}$ per day, meanwhile, in children, the body weight considered was $10 \mathrm{~kg}$ and average EDC contact was $1 \mathrm{~L}$ per day.

Table 4 shows the health risk values calculated for exposition to EDC in the studied sites. The site where children and adult dwellers are at major risk for contact with EDC, is " 10 de abril site". It is important to highlight that this exposition is only due to synthetic hormone $\mathrm{EE}_{2}$. Also, it is important to consider the shortage of information related with health risk exposure in Mexico, thus, it is relevant to create an historical record of EDC contained in surface waters, as well as to try to infer the probable health risk exposure. Although the site 10 de abril shows higher levels of health risk for exposition than all the other places, equally, it represents a risk for the exposed population.

Table 4. Health risk rate for exposition to EDCs.

\begin{tabular}{|c|c|c|c|c|}
\hline Site & Compound & $\begin{array}{l}\text { Concentration } \\
(\mathrm{ng} / \mathrm{mL})\end{array}$ & $\begin{array}{l}\text { Exposition Rate in Adults } \\
\left(\mathrm{mg} / \mathrm{kg}^{*} \text { day }\right)\end{array}$ & $\begin{array}{c}\text { Exposition Rate in Children } \\
\left(\mathrm{mg} / \mathrm{kg}^{*} \text { day }\right)\end{array}$ \\
\hline 10 de abril & $\mathrm{EE}_{2}$ & 624 & 6.5 & 22.8 \\
\hline Guacamayas & $\mathrm{EE}_{2}$ & 31.2 & 0.3 & 1.1 \\
\hline \multirow{2}{*}{ A la presa } & $\mathrm{NP}$ & 85.5 & 0.9 & 3.1 \\
\hline & $\mathrm{EE}_{2}$ & 91.5 & 1.0 & 3.3 \\
\hline \multirow{2}{*}{ Josefa Ortiz I } & BPA & 39.1 & 0.4 & 1.4 \\
\hline & $\mathrm{EE}_{2}$ & 182 & 1.9 & 6.6 \\
\hline Josefa Ortiz II & $\mathrm{EE}_{2}$ & 232 & 2.4 & 8.5 \\
\hline Jiutepec centro (canal) & $\mathrm{EE}_{2}$ & 138 & 1.4 & 5.1 \\
\hline \multirow{2}{*}{ Jiutepec centro } & BPA & 8.72 & 0.9 & 3.2 \\
\hline & $\mathrm{EE}_{2}$ & 148 & 1.5 & 5.4 \\
\hline \multirow{2}{*}{ Las Moras } & BPA & 40.3 & 0.4 & 1.5 \\
\hline & $\mathrm{EE}_{2}$ & 91.4 & 1.0 & 3.3 \\
\hline Calera Chica & BPA & 175 & 1.8 & 6.4 \\
\hline
\end{tabular}

Exposition frequency $=365$ days/year; Average body weight for adults $=70 \mathrm{~kg}$ and $10 \mathrm{~kg}$ for children; Contact rate for adults $=2 \mathrm{~L} /$ day and $1 \mathrm{~L} /$ day for children. 


\section{Conclusions}

The optimized methodology allowed analysis of NP, BPA, $\mathrm{E}_{2}$ and $\mathrm{EE}_{2}$ simultaneously by GC-MS. The selectivity of the method was verified by the injection of the mixture of the four compounds of interest, and the method presented good linearity and acceptable percentages of recovery according to the criteria of the EPA.

The analysis of the real samples indicates that the levels of EDCs in the bodies of natural water studied in the state of Morelos exceed the levels proposed by the USEPA and the EU, which constitutes a risk to the health of the exposed population. It is worth mentioning that this is one of the first studies carried out in this part of the republic, so it is recommended to carry out a wider diagnosis in various sources of natural water in the state.

Although, at present, there is no standard in Mexico that establishes maximum permissible levels of exposure to EDCs, it is important to calculate the exposure rates, so that the authorities responsible for creating environmental and health protection policies can use this type of information for their implementation.

Author Contributions: All authors participated in the same proportion.

Funding: This research received no external funding.

Acknowledgments: The authors would like to express their appreciation to Tec. María Gregoria Medina Pintor and M. Sc. Mònica Ivonne Arias Montoya for their support in the chromatographic analysis.

Conflicts of Interest: The authors declare no conflict of interest.

\section{References}

1. Campbell, C.G.; Borglin, S.E.; Green, F.B.; Grayson, A.; Wozei, E.; Stringfellow, W.T. Biologically directed environmental monitoring, fate, and transport of estrogenic endocrine disrupting compounds in water: A review. Chemosphere 2006, 65, 1265-1280. [CrossRef] [PubMed]

2. Azpilcueta, M.E.; Pedroza, A.; Sanchez, I.; Salced, M.; Del, R.; Trejo, R. Calidad química de agua en un área agrícola de maíz forrajero (Zea mays L.) en la Comarca Lagunera, México. Rev. Int. Contam. Ambient. 2017, 33, 75-83. [CrossRef]

3. Chacón, K.O.; Pinedo, C.; Rentería, M. Evaluación de elementos traza en agua de río y manantial del área minera de Ocampo, Chihuahua, México. Rev. Int. Contam. Ambient. 2016, 32, 375-384. [CrossRef]

4. Guzmán-Colis, G.; Thalasso, F.; Ramírez-López, E.M.; Rodríguez-Narciso, S.; Guerrero-Barrera, A.L.; Avelar-González, F.J. Evaluación espacio-temporal de la calidad del agua del río San Pedro en el Estado de Aguascalientes, México. Rev. Int. Contam. Ambient. 2011, 27, 115-127.

5. Mancilla-Villa, Ó.R.; Ortega-Escobar, H.M.; Ramírez-Ayala, C.; Ramos-Bello, R.; Reyes-Ortigoza, A.L. Metale pesados totales y arsénico en el agua para riego de Puebla y Veracruz, México. Rev. Int. Contam. Ambient. 2012, 28, 39-48.

6. CEAGUA. Programa Estatal Hídrico de Morelos 2014-2018. Available online: http:/ / marcojuridico.morelos. gob.mx/archivos/reglamentos_estatales/pdf/VPHIDRICOMO.pdf (accessed on 16 January 2018).

7. CONAGUA. La Cuenca del río Apatlaco. Recuperemos el Patrimonio Ambiental de los Morelenses 2008. Available online: http://centro.paot.org.mx/documentos/semarnat/cuenca_rio_apatlaco.pdf (accessed on 11 January 2017).

8. EPA. Method 1698: Steroids and Hormones in Water, soil, Sediment, and Biosolids by HRGC/HRMS; EPA Method; EPA: Washington, DC, USA, 2007; pp. 1-69.

9. Miller, J.N.; Miller, J.C. Statistics and Chemometrics for Analytical Chemistry, 6th ed.; Pearson Education: Harlow, UK, 2010; pp. 124-126. ISBN 978-0-273-73042-2.

10. INEGI. Anuario Estadístico y Geográfico de Morelos 2016. Available online: http://internet.contenidos. inegi.org.mx/contenidos/Productos/prod_serv/contenidos/espanol/bvinegi/productos/nueva_estruc/ anuarios_2016/702825084349.pdf (accessed on 25 January 2018).

11. Gibson, R. Determination of acidic pharmaceuticals and potential endocrine disrupting compounds in wastewaters and spring waters by selective elution and analysis by gas chromatography-mass spectrometry. J. Chromatogr. A 2007, 1169, 31-39. [CrossRef] [PubMed] 
12. Díaz Torres, E.; Gibson, R.; González Farías, F.; Zarco Arista, A.E.; Mazari Hiriart, M. Endocrine disruptors in the Xochimilco Wetland, Mexico City. Water Air Soil Pollut. 2013, 224, 1-11. [CrossRef]

13. EPA. EPA-HQ-OPPT-2010-0812-0001 (Testing of Bisphenol A). Revised 20 April 2017. Available online: https: / / www.regulations.gov / document?D=EPA-HQ-OPPT-2010-0812-0001 (accessed on 2 February 2018).

14. EPA. EPA-822-R-05-005: Aquatic Life Ambient Water Quality Criteria Nonylphenol. Available online: www.epa.gov/waterscience/criteria/aqlife.html (accessed on 2 February 2018).

15. Scientific Committee on Health and Environmental Risks (SCHER). Opinion on Draft Environmental Quality Standards under the Water Framework Directive-17ß-estradiol; European Commission, DG Health \& Consumers, Directorate C: Public Health and Risk Assessment, Unit C7-Risk Assessment: Bruselas, Belgium, 2011. Available online: https:/ / ec.europa.eu/health/scientific_committees/environmental_risks/ docs/scher_o_131.pdf (accessed on 2 February 2018). [CrossRef]

16. Scientific Committee on Health and Environmental Risks (SCHER). In Opinion on Draft Environmental Quality Standards under the Water Framework Directive-Ethinylestradiol; European Commission, DG Health \& Consumers, Directorate C: Public Health and Risk Assessment, Unit C7-Risk Assessment: Bruselas, Belgium, 2011. Available online: https:/ / ec.europa.eu/health/scientific_committees/environmental_risks/ docs/scher_o_146.pdf (accessed on 2 February 2018). [CrossRef]

17. EPA. Ecological Risk Assessment Guidance for Superfund: Process for Designing and Conducting Ecological Risk Assessments, 239. Available online: https:/ /www.epa.gov/risk/ecological-risk-assessment-guidancesuperfund-process-designing-and-conducting-ecological-risk (accessed on 2 February 2018).

(C) 2018 by the authors. Licensee MDPI, Basel, Switzerland. This article is an open access article distributed under the terms and conditions of the Creative Commons Attribution (CC BY) license (http:/ / creativecommons.org/licenses/by/4.0/). 